\title{
7. Do market forces reduce segregation? The controversies of post-socialist urban regions of Central and Eastern Europe* Zoltán Kovács
}

\subsection{INTRODUCTION}

Residential segregation is usually approached as the study of the uneven spatial distribution of various population groups in cities. The issue comes especially to the fore when there are radical changes in the basic principles that shape the spatial equilibrium of socioeconomic groups (Sýkora, 2009b). In Central and Eastern Europe (CEE) there have been two turning points and profound reshuffling in socio-economic development in the last seven decades. We use the term CEE as a political geographical region which was created by the political division of Europe after 1945. These countries were involuntarily diverted to a distinct political and socio-economic development path after World War II under strict Soviet control. For nearly half a century these countries constituted a zone of transition between Western Europe and the Soviet Union, covering the German Democratic Republic (GDR), Poland, Czechoslovakia, Hungary, Yugoslavia, Albania, Bulgaria and Romania (Dingsdale, 1999; Rugg, 1985) (Figure 7.1). Since the three Baltic republics (Estonia, Latvia and Lithuania) have always formed a distinctive unit in the Soviet Union according to their culture and socio-economic development, and they could be perceived as part of Western European civilisation, the present study also includes these countries.

From the late 1940s in state-socialist CEE the role of the market was severely limited (partly abolished). Homogenisation and egalitarianism became the main principle in societal life (Enyedi, 1996). Collective ownership of urban land and infrastructure prevailed; resources were allocated through the system of central planning. However, these countries differed not only from the West, but also from the Soviet model, as they mixed legacies from their past with Marxist-Leninist principles as far as their political system, welfare regime and housing policy were concerned.

Even though CEE countries belonged to the hinterland of Moscow for nearly half a century, and they followed more or less the same ideological profile, it is difficult to make generalisations about their urban development processes. This is mainly because countries of the region were at different stages of urbanisation on the advent of state socialism. Their urban forms exhibited clear differences. In 1950 the region was overwhelmingly rural: the share of urban population hardly reached 20 per cent in Albania, Bulgaria and Yugoslavia, 30 per cent in Romania and Poland and 40 per cent in Hungary. Only Czechia and Eastern Germany could be regarded as relatively urbanised regions. Cities in the more developed north-western regions (i.e. Eastern Germany, Western Poland, Czechia) resembled West European cities with functioning local governments, densely built urban structures and a relatively thick middle class, whereas regions of the south-east (e.g. Balkans) entered modern urbanisation only in the 20th century. Consequently, the urban 
This is a draft chapter. The final version is available in Handbook of Urban Segregation edited by S. Musterd, published in 2020, Edward Elgar Publishing Ltd. http://dx.doi.org/10.4337/9781788115605

The material cannot be used for any other purpose without further permission of the publisher, and is for private use only.

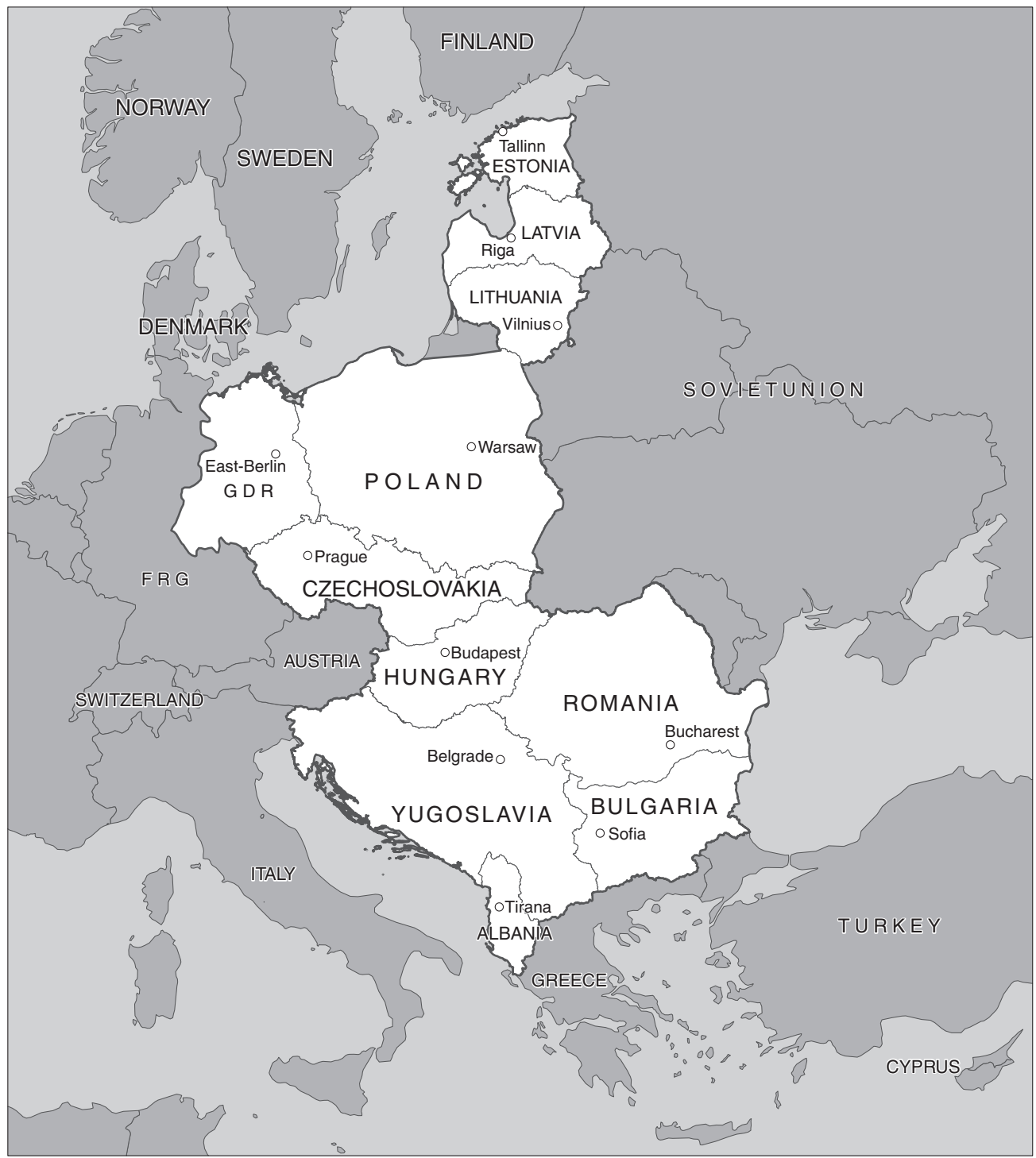

Figure 7.1 CEE countries

network was poorly developed with very few real urban places. These differences were, to some extent, levelled out during state-socialist urbanisation; nevertheless, legacies of the past remained palpable regarding urban spatial formations and social life until most recently.

In 1989-1990 these countries arrived at a turning point in their development again, when the collapse of the state-socialist system, the dismantling of central planning, the shift to a market economy and the widening gap in income distribution increased socio-economic differences in these societies, resulting in new socio-spatial differentiation (Brade et al., 
This is a draft chapter. The final version is available in Handbook of Urban Segregation edited by S. Musterd, published in 2020, Edward Elgar Publishing Ltd. http://dx.doi.org/10.4337/9781788115605

The material cannot be used for any other purpose without further permission of the publisher, and is for private use only.

\section{Handbook of urban segregation}

2009). However, the pace of post-socialist transition was not uniform in the region. In the so-called fast-track reforming countries, namely the Visegrad countries (Poland, Czechia, Slovakia and Hungary) and Baltic states (Estonia, Latvia and Lithuania), the return to capitalism was relatively swift and the process of systemic changes was completed by the early 2000s (Marcińczak et al., 2015). Consolidation of the housing market, the emergence of new housing classes and the reorganisation of the socio-spatial structure of cities was relatively smooth, even though this group of countries provides a variety of models when it comes to welfare and housing regimes. In member states of the former Yugoslavia (except for Slovenia), Romania, Bulgaria and Albania the transition to the market economy was less straightforward. Developments in the housing market often resembled those of the less developed countries (including a high level of informality, war destruction etc.), while the elite groups of socialism successfully transferred most of their previous privileges to the new post-socialist era.

The main aim of this chapter is to provide a broad overview of the changes in the sociospatial segregation of post-socialist CEE cities. After 1989-1990 the underlying factors of social development abruptly changed in these countries: welfare state retrenchment, commodification, globalisation and economic restructuring were common in the region. All these resulted in rising income inequalities, and the question was put forward of how growing social inequalities under market conditions are translated into spatial inequalities. In this chapter, after summarising the mechanisms of socio-economic segregation during state socialism, we focus on the framework conditions of residential segregation in CEE after 1989-1990. This is followed by an analysis of the main features of contemporary segregation patterns in post-socialist cities based mainly on existing literature. Finally, we draw some conclusions which go beyond the post-socialist segregation debate.

\subsection{URBAN SOCIETIES IN CEE DURING STATE SOCIALISM}

In the introductory chapter of their seminal book on socialist cities, French and Hamilton (1979) posed the basic question of whether cities of socialism were fundamentally different from what may be called a capitalist city. One of the key arguments behind their positive answer was the generally lower level of segregation in cities of state socialism, or in other words, the more intense mixing of different social groups. One important aspect of difference was, surely, that in CEE countries the state had the power to determine the pace and the form of urban development to a much greater extent than in Western societies.

City regions of CEE became subjects of the egalitarianism of the state-socialist system after World War II. Solutions to urban problems including poverty, socio-economic polarisation and segregation were sought within a philosophical framework of Marxist doctrine and with tools provided by central planning and a very generous welfare regime (French and Hamilton, 1979). State-socialist governments had the power to intervene in the process of urbanisation and urban development, and they set the objective that 'urbanisation should be planned and egalitarian' (Enyedi, 1996). The high level of control was enabled by the dominance of state ownership of land and real estate and by the centrally planned allocation of development funds.

State socialism changed the contents and functioning of urban societies. The wealthiest sections of the former landlord and capitalist elites were liquidated or emigrated to the 
This is a draft chapter. The final version is available in Handbook of Urban Segregation edited by S. Musterd, published in 2020, Edward Elgar Publishing Ltd. http://dx.doi.org/10.4337/9781788115605

The material cannot be used for any other purpose without further permission of the publisher, and is for private use only.

Do market forces reduce segregation?

West, the urban middle class shrunk, and proletarisation, in which most people became state employees, became widespread (Enyedi, 1996). Instead of autonomous, individual decisions made by citizens, centrally designated and strictly controlled rules started to dominate urban life, including residential mobility, leisure and lifestyle. Strict wage regulation, mass housing production and centralised housing allocation systems aimed at homogenisation and social mixing within urban societies. It was commonly believed that inequalities inherited from the capitalist past would sooner or later disappear in the process of socialist urban development.

Housing became a fundamental element of the state-socialist welfare system. Capitalist production and distribution of housing blamed for the previous inequalities was effectively abolished. State ownership of land and property was achieved through forceful nationalisation programmes. Most of the properties and dwellings of the former bourgeoisie were confiscated and transferred to public ownership. Subdivision of bigger housing units into smaller apartments was also frequent in urban areas. The state became the dominant player in urban housing, which not only built and operated the public dwelling stock, but also controlled the functioning of other non-public sectors (co-ops, associations, company housing etc.). Housing was proclaimed to be a universal right; simultaneously, housing production became standardised, and increasingly concentrated in large housing estates with uniform layout and amenities. It was, nevertheless, more difficult to apply egalitarian principles in the older housing stock. Local authorities tried to do so by partitioning bigger apartments and villas and by multi-occupancy of larger units. As a consequence, the level of socio-economic segregation abruptly and generally decreased in CEE cities after World War II, although we must note that it did not disappear completely. This was because despite repeated efforts, certain distinctive forms of socio-spatial inequality persisted, while some new ones evolved. The reasons behind this were as follows.

First of all, cities are rigid systems, and inherited physical and socio-spatial patterns change only slowly. As several studies revealed, the pre-World War II ecological structure of cities changed only slowly, and patterns of segregation remained astonishingly stable over time. As Kovács (1990) noted, the elegant villa quarters of the Buda Hills were still in sharp contrast with the overcrowded and low-quality tenement blocks of the inner city in Budapest in the 1980s. In a similar vein, even though the already low level of segregation further decreased in Prague after 1945 (Ouředníček et al., 2016), distinct socio-economic differences between the traditional villa quarters of Prague's West End and some of the poorer working-class neighbourhoods (e.g. Holešovice, Smíchov) persisted. Neighbourhoods with traditionally high prestige existed in most of the cities throughout the whole period.

Second, even though these countries followed the Soviet model in formulating their policy goals, the attitude of people making their decisions regarding job, housing, services or leisure could not be changed overnight. Individual goals remained independent from ideological considerations and they focused on well-paid jobs, adequate housing, good quality services and a neighbourhood with good prestige (Enyedi, 1996). In this respect the difference between Eastern and Western Europe was really negligible in the post-war period. People's individual aspirations expressed a certain tradition of shared European culture and went against the policy goals of state-socialist governments. For instance, people did not accept the egalitarian goal with respect to housing; rather, they attempted to raise their social status by moving to better regarded neighbourhoods. 
This is a draft chapter. The final version is available in Handbook of Urban Segregation edited by S. Musterd, published in 2020, Edward Elgar Publishing Ltd. http://dx.doi.org/10.4337/9781788115605

The material cannot be used for any other purpose without further permission of the publisher, and is for private use only.

\section{Handbook of urban segregation}

Third, state-socialist ideology and urban policy also changed over time and diverted from the orthodox myth of 'classless society'. From the 1960s onwards Stalinist-type ideological goals were gradually replaced by technocratic considerations in urban policy, when it was realised that urban processes cannot be planned completely in a normative way (this was the case most clearly in Poland, Hungary and Yugoslavia). With time, market elements were introduced in some domains of the economy and the slogan of egalitarianism was combined with that of efficiency in official policy documents (Tammaru et al., 2016b). Encouragement was given to private housebuilding and other semi-private forms of housing (e.g. co-operatives), especially in urban areas (Hegedüs and Tosics, 1983; Ouředníček et al., 2016). As a consequence, a socialist mixed-housing system evolved in most of the countries, opening the way to quasi-market elements (often in the form of a black market) and a more pronounced spatial separation of better-off groups from the rest of the society (Musil, 1993).

Fourth, state socialism was characterised by a permanent shortage of goods, services and housing (Kornai, 1992). Governments were unable to meet their promises regarding the output of housing, infrastructure and public services (Enyedi, 1996). Egalitarianism under conditions of shortages necessarily creates inequalities. Privileged social groups and individuals managed to utilise their advantages also in socio-spatial terms. As it was noted by Szelényi (1987), the nomenklatura (i.e. party apparatus, leaders of the public administration), the managerial and cultural elite, and members of the armed forces always had access to better housing and services than blue-collar workers, and they occupied the most prestigious and environmentally most attractive parts of cities under state socialism. As Häussermann (1996, p. 222) noted, cities of the former GDR were characterised by 'the absence of classical forms of segregation (i.e. by income) but, instead, there was discrimination by politically distributed privileges'. In addition, in some of these countries (e.g. Poland, Hungary, countries of the Balkans) the so-called second economy (or shadow economy) gradually evolved next to the centrally planned first economy, which enabled the emergence of new socio-economic inequalities. Services, goods and housing construction related to the second economy provided an additional income for a growing number of households. According to Iván Szelényi (1989), by the mid-1980s 70 per cent of the households in Hungary earned incomes from the second economy, and about a fifth of the active earners received a third or half of their income from private business activities.

All the above factors sustained social segregation in cities of state-socialist CEE, though with varying intensity in the different countries (Ruoppila, 2004). In socialist states where market elements survived in the economy (e.g. agriculture, petit commerce) for political reasons, and a second economy was allowed, income differences and, thus, segregation were more pronounced, although still below the West European dimensions. To this group belonged Poland, Hungary, member states of the former Yugoslavia and, to some extent, Bulgaria. In other, more egalitarian, or we may say neo-Stalinist, regimes (e.g. Czechoslovakia, GDR, Romania and the Baltic states under Soviet control), socioeconomic differences were less pronounced, and the level of segregation was also lower. There is more or less agreement among authors that CEE cities did not show signs of social polarisation during the socialist era and socio-spatial disparities either stagnated or lowered (French and Hamilton, 1979; Musil, 1993; Szelényi, 1987).

What the whole of CEE had in common after 45 years of state socialism was a general dissatisfaction with the performance of the central planning system and a 'myth of the 
This is a draft chapter. The final version is available in Handbook of Urban Segregation edited by S. Musterd, published in 2020, Edward Elgar Publishing Ltd. http://dx.doi.org/10.4337/9781788115605

The material cannot be used for any other purpose without further permission of the publisher, and is for private use only.

Do market forces reduce segregation?

market'. On the one hand, there was an urgent need both politically and financially to improve the functioning and efficiency of the economy as many of these countries faced immense problems of liquidity (Kovács, 1999). On the other hand, there was a common belief that market mechanisms would be a more efficient way of organising the production and exchange of goods than the previous system of central planning (this was repeatedly 'implied' by organisations such as the International Monetary Fund (IMF) and the World Bank). When transformation started, these factors altogether led to the general dominance of neoliberal policies according to which only exclusive individual ownership and alienability of resources can provide the right incentives for their efficient use (Hann, 2005). The outcome was a radical shift from the centrally planned system to market regulation in nearly all the countries of CEE.

\subsection{FRAMEWORK CONDITIONS OF SOCIO-ECONOMIC SEGREGATION AFTER 1990}

Before we proceed any further with analysing actual trends of socio-spatial segregation in post-socialist cities, it is important to portray the general conditions that influenced social segregation in CEE cities after 1990. In the transition period single-party systems were changed for multiparty democracies; centrally planned control of prices, wages and the egalitarian distribution of services was abolished. In economic policy the main objective became privatisation of state assets (including public housing) in mass commodification programmes. Subsequently, the profound economic restructuring resulted in growing wage and income disparities which in turn started to reshape existing patterns of sociospatial differences.

There are two basic spheres of socio-economic life where all the changes implemented in the economic and political structure converge and which have a key role in the spatial articulation of cities; these are the labour market and the housing market. These two markets are closely linked and interrelated through the functioning of elements at the micro level, that is, by the choices and activities of individuals and households (Grime and Kovács, 2001). During state socialism inexpensive housing and secure jobs guaranteed by the state constituted the cornerstones of the welfare regime. With the radical shift from central planning to a free-market system, this model was changed abruptly after 1989 . The introduction of a capitalist economy meant that the market rather than government planning became the principal allocator for money, housing and services.

Due to economic restructuring, deindustrialisation, growing liberalisation and globalisation of capital and the labour force, the competition among firms sharply increased, which in turn resulted in occupational changes and growing wage inequalities in the labour market. As a consequence, the formerly fairly homogeneous urban labour markets became segmented, with increasing gaps between different occupational groups. The transformation of the housing market also sparked significant changes. High housing subsidies meant an enormous burden on national budgets; therefore it was no surprise that governments started a radical withdrawal from the housing market after the political changes. More than 90 per cent of the public housing stock was privatised during the 1990s (Hegedüs, 2013). This resulted in the emergence of super housing-ownership societies (Stevens et al., 2016). Indeed, as opposed to Western Europe, in the housing market 
This is a draft chapter. The final version is available in Handbook of Urban Segregation edited by S. Musterd, published in 2020, Edward Elgar Publishing Ltd. http://dx.doi.org/10.4337/9781788115605

The material cannot be used for any other purpose without further permission of the publisher, and is for private use only.

\section{Handbook of urban segregation}

of post-socialist CEE countries owner occupation dominates to an extreme, the private rental sector is marginal, and the public housing stock has become residualised.

Finally, let us consider the general factors of segregation. There is a near consensus in the literature that residential segregation in cities is basically the outcome of three intertwining structural factors: wealth inequality, the functioning of the housing market and ethno-religious differences (Tammaru et al., 2017). The role of wealth inequality is clear: the level of purchasing power basically determines who can reside in which part of a particular city. It is also more or less evident that in capitalist societies the pattern of segregation tends to be shaped by the wealthier sections of the society, who seek better-quality housing in better environments. The functioning of the housing market, the balance between demand and supply, is also important in shaping patterns of segregation; newly built or renovated dwellings provide excellent opportunities for the better-off strata to segregate themselves if the state does not intervene. The role of ethnicity and religion in residential segregation is also well documented in the literature; most research on segregation around the world focuses on this aspect. Living among similar people can have many benefits, such as a stronger sense of safety, shared services and facilities (such as shops, cultural and religious institutions), wider social networks and concomitant social capital (Clark, 1991).

In the case of post-socialist cities, we can say that the first two factors have had utmost importance in shaping segregation in the last decades, in the light of welfare state retrenchment, the redistribution of wealth and income along with the reshuffling of the housing market. However, ethnicity has played a subordinated role in post-socialist cities (at least compared to Western Europe), because due to historical reasons most of these countries are ethnically more or less homogeneous, and except for the Russian population in major cities of the Baltic countries (most notably in Estonia and Latvia) and the Roma population in some parts of CEE (i.e. cities of former Sudetenland in Czechia, Slovakia, Hungary and the Balkan states), the ethnic dimensions in socio-spatial segregation are generally weak. We must not forget here that these countries at the eastern periphery of Europe were not involved in the explorations and the colonisation process of the 16th-17th centuries. In fact, these countries were colonised by other European powers, most notably by Prussia, Austria, Russia and the Ottoman Empire. Typically, none of the present CEE states was independent at the beginning of the 19th century (Enyedi, 1996). Also, after World War II these countries were hermetically cut off from international migrations by the Iron Curtain. As a result, CEE cities lack enclaves of significant Asian and African population.

We also believe that socio-cultural factors of segregation - which are very much neglected by the mainstream literature - play a distinguished role here. As it was already noted, affluent people tend to congregate in the best parts of cities everywhere in the world, yet the level of segregation can be very different in various socio-cultural contexts. By socio-cultural contexts we mean how and to what extent the wealthy, socially and spatially mobile seek to separate themselves from others. Along with Szelényi (1996) we believe that segregation as part of 'urbanism' is also rooted in the socio-cultural development of societies which influences lifestyle, residential preferences, inter-group relations and the inclination of individuals to mix with others. We argue that lower levels of segregation in CEE countries before 1990 were not exclusively the result of state-socialist welfare policies. Industrial capitalism and modern urbanisation arrived in CEE with a 
This is a draft chapter. The final version is available in Handbook of Urban Segregation edited by S. Musterd, published in 2020, Edward Elgar Publishing Ltd. http://dx.doi.org/10.4337/9781788115605

The material cannot be used for any other purpose without further permission of the publisher, and is for private use only.

Do market forces reduce segregation?

considerable time lag compared to the West. Post-feudal elements of social stratification remained strong in most of these countries; wealth inequalities, especially in urban areas, were less pronounced than in the West. Most of the region was dominated by egalitarian peasant societies before World War II. The practice and norms of segregation were significantly different from Western societies; people's endeavour to mix with 'others' was generally stronger. This societal tradition remained an important factor during state socialism and even after.

\subsection{JANUS FACE OF SEGREGATION IN POST-SOCIALIST CITIES}

Despite the dynamically growing body of literature addressing some of the aspects of post-socialist urban transformation in CEE cities, empirical analyses on socio-economic segregation are relatively rare (Marcińczak et al., 2015; Kovács and Szabó, 2016; Krišjāne et al., 2016; Ouředníček et al., 2016; Tammaru et al., 2016a; Valatka et al., 2016). This is partly because these cities were in continuous transition in the first two decades after the collapse of state socialism, and under these unstable societal conditions it was hard to make any decisive judgement about long-term segregation processes. Also, as the pattern of residential segregation in CEE cities became more complex compared to the state-socialist period, the reliability of traditional indices provided by national censuses (e.g. data on education) in measuring social inequalities came to be questioned. There has been a growing awareness among researchers that traditional indicators obscure rather than reveal the new (capitalist) forms of socio-spatial inequalities in post-socialist cities (Sýkora, 2009b; Kovács and Szabó, 2016).

Writings about socio-spatial differentiation and residential segregation in post-socialist cities have presented two strands of theoretical interpretations. Some studies have suggested that growing income inequalities are inevitably translated to increasing housing inequalities and new territorial disparities (Smith and Timár, 2010). According to Węcławowicz (1998) the increase in social stratification, particularly the elite and poverty groups, has its spatial representation in the increase of spatial segregation through the housing market mechanism. Brade et al. (2009, p. 234) noted that 'polarizing consequences arising from locations being valorized according to market criteria have become a crucial ingredient in the dynamic change' of post-socialist cities. Other studies, supported with some census data, have suggested that despite growing income inequalities the level of residential segregation in post-socialist cities has not increased after the systemic changes as one would have expected (Musterd and Ostendorf, 2012), but on the contrary, it has lowered (Sýkora, 2009a; Marcińczak and Sagan, 2011; Marcińczak et al., 2013). Their explanation about the 'paradox of post-socialist segregation' seems to be fairly plausible: 'post-socialist segregation processes operate in their initial phases against the socialist heritage, bringing some higher social status neighbourhoods (housing estates) as well as lower social status zones (suburbanisation of rural hinterland) closer to the city average' (Sýkora, 2009a, p. 394). Even though authors hint at the possible temporary nature of the phenomenon, the whole argument goes against the expectations one would have imagined.

The reasons behind the seemingly decreasing levels of segregation are easy to grasp. As in market economies where the role of the public sector is weak, like in CEE, the patterns 
This is a draft chapter. The final version is available in Handbook of Urban Segregation edited by S. Musterd, published in 2020, Edward Elgar Publishing Ltd. http://dx.doi.org/10.4337/9781788115605

The material cannot be used for any other purpose without further permission of the publisher, and is for private use only.

\section{Handbook of urban segregation}

of residential segregation in cities are shaped predominantly by the wealthier, socially and spatially most mobile segments of society (e.g. Marcińczak et al., 2015; Kovács and Szabó, 2016). As the wealthier population moves to previously less prestigious areas where mostly lower-status people reside, the level of segregation necessarily decreases. In the post-1990 mobility pattern of CEE cities there were two main zones within city regions where younger and more affluent populations congregated: the periurban hinterland, and some inner-city neighbourhoods, both having previously a predominantly lower-class character.

Right after the systemic changes, higher social groups invaded the rural belt around cities in a spectacular suburbanisation process. The reasons were clear: what was impossible during state socialism due to administrative restrictions, lack of building plots and low levels of car ownership suddenly became a housing market option under neoliberal capitalism. People with higher social status sought better residential conditions outside the city, trying to fulfil their dream of having a detached house in an attractive suburban environment (Tammaru et al., 2009). Consequently, suburbanisation became a pervasive urban phenomenon throughout the region, often resulting in upmarket residential enclaves in otherwise traditional rural communities (Kok and Kovács, 1999; Kovács and Tosics, 2014; Leetmaa and Tammaru, 2007; Leetmaa et al., 2009; 2014; Ouředníček, 2007; Pichler-Milanović, 2014; Stanilov and Sýkora, 2012; Stanilov and Hirt, 2014).

After 2000, as suburban locations gradually became saturated and concomitant renovation activities increased within older city centres, the attention of the middle class and other more mobile 'new urbanites' (Haase et al., 2012) turned towards inner-city locations. In subsequent years, various hard and soft forms of gentrification (e.g. new-build gentrification, commercialisation, studentification) set into motion in the old housing stock, shaping intra-urban residential segregation (Górczyńska, 2017; Kährik et al., 2015; Kovács, 2009; Kovács et al., 2013; Sýkora, 2005). As Bernt et al. (2015) noted, gentrification in the second decade of transition was no longer just a small-scale process occurring only in capital cities, but an excessive and also increasingly present process happening in more peripheral, smaller cities in CEE.

Thus, the processes of suburbanisation and gentrification supported the catching-up discourse in post-socialist cities, on the one hand, which implies that the introduction of market economy inevitably leads to the replication of Western models of urban development (Bernt et al., 2015), and on the other hand, they also resulted in - seemingly - decreasing levels of segregation. These processes, however, increased social mix rather at the macro-geographical scale of urban zones or urban districts, even though the statistically depicted social mixing was not accompanied by any cohesion among local residents. Specific social groups became concentrated in small territorial units; pockets of wealth and poverty developed in close spatial proximity to each other (e.g. gated communities vs dilapidated brownfield locations), though with little interaction among residents. Conventional approaches to segregation fail to capture such situations where different social groups live next to each other in the same statistical units but without any connection. Under such circumstances no real social mixing is taking place, social networks at the local level are lacking, and rather parallel societies coexist. Suburbanisation and gentrification in post-socialist cities have provided excellent examples for the mosaic-type urban development without any social cohesion.

Empirical analyses on socio-economic segregation in post-socialist cities started to mushroom in the second decade after the turn of the millennium. This is probably because 
This is a draft chapter. The final version is available in Handbook of Urban Segregation edited by S. Musterd, published in 2020, Edward Elgar Publishing Ltd. http://dx.doi.org/10.4337/9781788115605

The material cannot be used for any other purpose without further permission of the publisher, and is for private use only.

the results of the 2011 censuses became available at that time, enabling longitudinal analysis of socio-spatial differences (Kovács and Szabó, 2016; Krišjāne et al., 2016; Ouředníček et al., 2016; Tammaru et al., 2016b; Valatka et al., 2016). The first rigorous cross-country comparison of socio-economic segregation in CEE by Marcińczak et al. (2015) showed that despite growing economic inequalities the level of segregation in five investigated post-socialist capital cities was either low or very low by international comparisons in $2000 .{ }^{1}$ Authors referred to the legacy of state socialism as a possible explanatory factor and to inertia effects that offset the 'immediate catalysing effect of economic liberalization, globalization, and growing socioeconomic inequality on the patterns of segregation, at least in the first decade after the collapse of socialism' (Marcińczak et al., 2015, p. 197).

Later on Tammaru et al. (2017), using 2001 and 2011 census data in a cross-country comparison, came to the conclusion that socio-economic inequalities unanimously increased in the investigated cities after the turn of the millennium. The level of socioeconomic segregation was measured by the dissimilarity index of the top and bottom socio-economic groups in five post-socialist cities (Budapest, Prague, Riga, Tallinn and Vilnius). Thus, as empirical evidence supported, income inequalities have been translated into new segregation patterns with a time lag in CEE cities. However, it is more important to emphasise that in the second decade after the downfall of state socialism the sociospatial division of cities clearly intensified (Figure 7.2).

Why did wealth inequalities that were accelerating from the early 1990s lead to higher levels of segregation in urban space with a significant delay? The answer seems to be fairly plausible: because the built environment means a certain inertia and in addition the level of residential mobility has been traditionally low in post-socialist CEE countries.

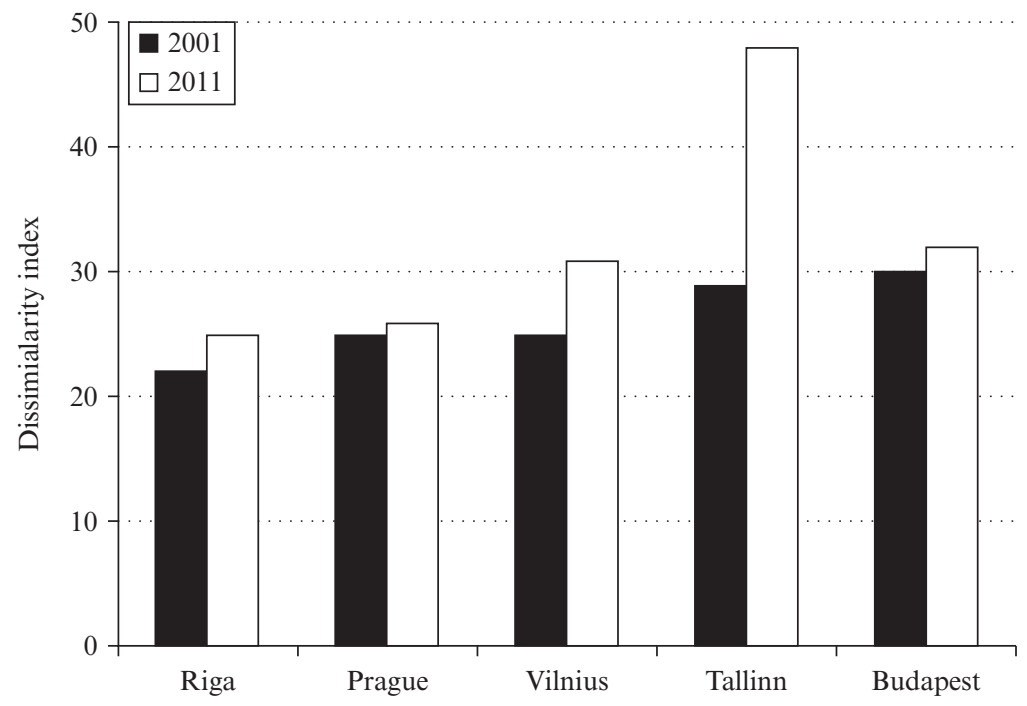

Source: Tammaru et al. (2017).

Figure 7.2 Changes in the dissimilarity index between top and bottom socio-economic groups between 2001 and 2011 
This is a draft chapter. The final version is available in Handbook of Urban Segregation edited by S. Musterd, published in 2020, Edward Elgar Publishing Ltd. http://dx.doi.org/10.4337/9781788115605

The material cannot be used for any other purpose without further permission of the publisher, and is for private use only.

\section{Handbook of urban segregation}

Residential mobility is closely tied to the functioning of housing markets and has important implications for residential segregation patterns. Caldera Sánchez and Andrews (2011) analysed the level of residential mobility across Organisation for Economic Co-operation and Development (OECD) countries and found that residential mobility tends to be relatively high in the Western and Nordic countries, while it is much lower in Eastern and Southern European countries. Mobility measured by the percentage of households that changed residence within the last two years was highest in the Nordic countries (well above 20 per cent), Australia (24 per cent) and the United States ( 21 per cent), and lowest in Eastern European countries (between 5-10 per cent) in the analysed sample. The share of households that changed residence within the last two years was, for example, 29 per cent in Iceland, 23 per cent in Sweden and 21 per cent in Norway, whereas it was only 4 per cent in Slovenia, the Slovak Republic and Poland, and 5 per cent in Czechia (Caldera Sánchez and Andrews, 2011). Survey data of Eurostat also confirm this picture (Eurostat, 2017). Almost half (46.9 per cent) of the city-dwellers in Sweden in 2012 had moved during the five years prior to the survey, and the share was also over 40 per cent among city-dwellers in Denmark. However, in several southern and eastern EU member states, it was relatively common to find that less than 10 per cent of the urban population had moved during the previous five-year period. These low levels of residential mobility were particularly pronounced in post-socialist Bulgaria and Romania, where less than 5 per cent of city-dwellers had moved during the previous five-year period.

Higher homeownership rates are commonly associated with lower residential mobility. In the North American context, Shlay (2015) demonstrated how growing homeownership contributes to housing immobility - one of the explanations given for falling mobility in the United States, even in response to regional economic problems. This is very similar to the effects of post-socialist transformation. Due to the almost complete commodification of the existing public housing stock, CEE countries created super homeownership tenure after 1990 (Tammaru et al., 2017). As the private rental sector had already been completely abolished after World War II, owner-occupied housing became dominant in the majority of CEE cities, which meant an obstacle for higher mobility rates. In addition, on the supply side of the housing market the number of new residential developments was seriously limited by economic depression, the lack of interest of foreign capital, and the lack of a functioning mortgage system in the 1990s. It is also known that changes in segregation pattern are significantly influenced by new housing construction. In the first decade after the collapse of state socialism, new residential investments were typically small-scale, often self-built units, and concentrated predominantly in the suburban belt around cities. Wealthier people and those who benefited most from housing privatisation used the opportunity and left for new residential areas in the suburbs (Kährik and Tammaru, 2008; Kok and Kovács, 1999; Ouředníček, 2007). Therefore, segregation levels did not change much in urban space; wealth inequalities could not be translated into more marked socio-spatial differences.

However, the second decade after the fall of socialism brought about significant changes in segregation patterns with increasing trends towards greater segregation. The reasons were clearly related to housing market effects and residential mobility. The growing purchasing power of individuals due to economic upswing, the development of the mortgage market, and the appearance of Western developers in the housing market after EU accession increased both the demand and supply in the housing markets of cities. New 
This is a draft chapter. The final version is available in Handbook of Urban Segregation edited by S. Musterd, published in 2020, Edward Elgar Publishing Ltd. http://dx.doi.org/10.4337/9781788115605

The material cannot be used for any other purpose without further permission of the publisher, and is for private use only.

Do market forces reduce segregation?

housing constructions served predominantly the needs of better-off people. Upmarket enclaves of various forms of housing (e.g. gated communities, inner-city residential towers, row houses) have appeared in many parts of the cities as symptomatic features of growing social inequalities and globalisation. Former working-class neighbourhoods have become renovated by regeneration programmes, making room for gentrification and population displacement. All these changes reflect important changes in the socio-spatial differentiation of cities, a 'splintering urbanism' and increasing levels of segregation.

\subsection{CONCLUSIONS}

As it is often claimed in the literature, due to deindustrialisation, globalisation and neoliberalisation, the socio-spatial divisions of cities tend to increase worldwide (Marcińczak et al., 2016). The size of the spatial gap between poor and rich hinges upon country/ region-specific institutional settings and historical development paths. In this respect post-socialist CEE countries provide an opportunity to study the consequences of abrupt changes in the wider political and socio-economic context. As has been demonstrated in this chapter, cities of CEE have shown several twists and turns in the last decades as far as welfare policy, social stratification, urban social relations and the spatial configuration of segregation are concerned. As Szelényi (1996) depicted, the ecological structure of CEE cities was quite similar to many Western cities before World War II. The wealthy groups of the society lived in prestigious inner-city neighbourhoods and the immigrant workingclass people settled in the outskirts, often beyond the city boundaries. However, as the state became the main agent of maintaining, building and allocating urban housing after 1945, the spatial structure of state-socialist cities started to change. On the one hand, the inner-city housing stock became nationalised and converted to public rental dwellings. As rents were kept low (5-10 per cent of average income) in order to match the low wages, the quality of the housing stock deteriorated, leading to social downgrading (Musil, 1993). On the other hand, due to financial considerations, almost all new housing constructions were concentrated in large housing estates, on the outskirts of cities (Hamilton, 1979). As the level of comfort in the new housing estates was much higher than in inner-city locations, the middle class started to migrate to the newly developed housing areas, whereas inner-city neighbourhoods began to attract lower-status people, mostly from the countryside. These processes led to the gradual rearrangement of the population in urban space, although cities of state socialism remained less segregated and spatially more compact than Western cities (Szelényi, 1987).

After 1989-1990 the ecological structure of post-socialist cities started to change again. On the one hand, the previously so desired pre-fab housing estates became re-evaluated by people and lost their popularity. Those who could afford to leave the housing estates left shortly after the transition, mainly to the suburbs. As a consequence, housing estates started to lose the relatively high status they used to enjoy, whereas the social status of suburbs gradually increased; though we must also note that social erosion in large housing estates has not been extreme, and several studies confirmed that they still preserve a great deal of social mix (Kährik and Tammaru, 2010; Kovács and Herfert, 2012). In the late 1990 s inner-city locations also became re-evaluated. As regeneration programmes succeeded, the top socio-economic groups started to move into formerly low-status 
This is a draft chapter. The final version is available in Handbook of Urban Segregation edited by S. Musterd, published in 2020, Edward Elgar Publishing Ltd. http://dx.doi.org/10.4337/9781788115605

The material cannot be used for any other purpose without further permission of the publisher, and is for private use only.

\section{Handbook of urban segregation}

neighbourhoods, setting into motion a process of gentrification. As Tammaru et al. (2016c) noted, gentrification often lowers levels of segregation in its early phase, as higher social groups start to move into formerly working-class neighbourhoods, which causes more social mix. But desegregation effects soon disappear once gentrification reaches a more mature phase, and this is what we can expect in the future.

The example of CEE cities illustrates that even though state socialism fell in 1989-1990, its distinct features regarding residential segregation and urban forms still survive. Growing socio-economic disparities could not immediately be manifested in a new, capitalist type of segregation pattern during the early transition period, mainly because of housing market constraints and socio-spatial processes (e.g. suburbanisation, gentrification) that temporarily created more social mix. It took more than a decade, when new housing constructions and renovations started to trigger new residential mobility flows and intensified residential segregation in post-socialist cities. Thus, the answer to the question formulated in the title of this chapter is definitely 'No'. Market conditions, growing neoliberalisation and competition obviously increase inequalities, not only among economic actors, but also within the societies, but these inequalities manifest in space with considerable time lag. Another important question is how socio-spatial segregation in cities of CEE will change in the future. It is difficult to give a rigorous prognosis for the whole region, but in the light of contemporary welfare state restructuring, an increasing reliance on owneroccupancy and the growing role of private actors in housing construction, it is safe to say that the level of segregation will further increase and the catching-up process with the West will continue (Musterd et al., 2017). We think that future studies should focus on the small-scale mechanisms of spatial segregation rather than neighbourhoods, districts or larger urban zones, as the fabric of segregation will become much finer as an outcome of splintering urbanism.

\section{NOTES}

* Funding for the work leading to this publication was received from the Hungarian Scientific Research Fund (OTKA) Grant Agreement No. K119710, from the Ministry for Innovation and Technology, Hungary, Grant TUDFO/47138-1/2019-ITMand from the Ministry of Human Capacities, Hungary, Grant 20391-3/2018/FEKUSTRAT.

1. The group of investigated cities included Budapest, Prague and Warsaw respresenting the Visegrad countries, and Tallinn and Vilnius from the Baltic states. Authors used occupational categories according to ISCO (International Standard Classification of Occupations) for measuring the segregation of different socio-economic groups. As the occupational position of a person strongly correlates with his or her educational and income levels, and thus socio-economic status, it is well suited to examining social disparities (Marcińczak et al., 2015).

\section{REFERENCES}

Bernt, M., Gentile, M. and Marcińczak, S., 2015. Gentrification in post-communist countries: An introduction, Geografie, 120(2), pp. 104-112.

Brade, I., Herfert, G. and Wiest, K., 2009. Recent trends and future prospects of socio-spatial differentiation in urban regions of Central and Eastern Europe: A lull before the storm? Cities, 26(5), pp. 233-244.

Caldera Sánchez, A. and Andrews, D., 2011. Residential mobility and public policy in OECD countries. OECD Journal: Economic Studies, Vol. 2011/1. http://dx.doi.org/10.1787/eco_studies-2011-5kg0vswqt240. 
This is a draft chapter. The final version is available in Handbook of Urban Segregation edited by S. Musterd, published in 2020, Edward Elgar Publishing Ltd. http://dx.doi.org/10.4337/9781788115605

The material cannot be used for any other purpose without further permission of the publisher, and is for private use only.

Do market forces reduce segregation?

Clark, W.A.V., 1991. Residential preferences and neighbourhood racial segregation: A test of the Schelling segregation model. Demography, 28(1), pp. 1-19.

Dingsdale, A., 1999. Redefining 'Eastern Europe': A new regional geography of post-socialist Europe? Geography, 84(3), pp. 204-221.

Enyedi, G., 1996. Urbanization under socialism. In: G. Andrusz, M. Harloe and I. Szelényi, eds. Cities after Socialism: Urban and Regional Change and Conflict in Post-Socialist Societies. Oxford: Blackwell, pp. 100-118.

Eurostat, 2017. Urban Europe: Statistics on cities, towns and suburbs - housing in cities. Statistics Explained. http://ec.europa.eu/eurostat/statisticsexplained/.

French, R.A. and Hamilton, F.E.I., 1979. Is there a socialist city? In: R.A. French and F.E.I. Hamilton, eds. The Socialist City: Spatial Structure and Urban Policy. Chichester: John Wiley \& Sons, pp. 1-22.

Górczyńska, M., 2017. Gentrifiers in the post-socilist city? A critical reflection on the dynamics of middle and upper-class professional groups in Warsaw. Environment and Planning A: Economy and Space, 49(5), pp. 1099-1121.

Grime, K. and Kovács, Z., 2001. Changing urban landscapes in East Central Europe. In: D. Turnock, ed. East Central Europe and the Former Soviet Union: Environment and Society. London: Edward Arnold, pp. 130-139.

Haase, A., Grossmann, K. and Steinführer, A., 2012. Transitory urbanites: New actors of residential change in Polish and Czech inner cities. Cities, 29(5), pp. 318-326.

Hamilton, F.E.I., 1979. Spatial structure in East European cities. In: R.A. French and F.E.I. Hamilton, eds. The Socialist City: Spatial Structure and Urban Policy. Chichester: John Wiley \& Sons, pp. 195-262.

Hann, C.M., 2005. Postsocialist societies. In: J.G. Carrier, ed. A Handbook of Economic Anthropology. Cheltenham, UK and Northampton, MA, USA: Edward Elgar Publishing, pp. 547-557.

Häussermann, H., 1996. From the socialist to the capitalist city: Experiences from Germany. In: G. Andrusz, M. Harloe and I. Szelényi, eds. Cities after Socialism: Urban and Regional Change and Conflict in PostSocialist Societies. Oxford: Blackwell, pp. 214-231.

Hegedüs, J., 2013. Housing privatisation and restitution. In: J. Hegedüs, N. Teller and M. Lux, eds. Social Housing in Transition Countries. New York: Routledge, pp. 33-49.

Hegedüs, J. and Tosics, I., 1983. Housing classes and housing policy: Some changes in the Budapest housing market. International Journal of Urban and Regional Research, 7(4), pp. 467-494.

Kährik, A. and Tammaru, T., 2008. Population composition in new suburban settlements of the Tallinn metropolitan area. Urban Studies, 45(5-6), pp. 1055-1078.

Kährik, A. and Tammaru, T., 2010. Soviet prefabricated panel housing estates: Areas of continued social mix or decline? The case of Tallinn. Housing Studies, 25 (2), pp. 201-219.

Kährik, A., Novák, J., Temelová, J., Kadarik, K. and Tammaru, T., 2015. Patterns and drivers of inner city social differentiation in Prague and Tallinn. Geografie, 120(2), pp. 274-294.

Kok, H. and Kovács, Z., 1999. The process of suburbanization in the agglomeration of Budapest. Netherlands Journal of Housing and the Built Environment, 14(2), pp. 119-141.

Kornai, J., 1992. The Socialist System. Oxford: Oxford University Press.

Kovács, Z., 1990. Rich and poor in the Budapest housing market. In: C.M. Hann, ed. Market Economy and Civil Society in Hungary. London: Frank Cass, pp. 110-124.

Kovács, Z., 1999. Cities from state-socialism to global capitalism: An introduction. GeoJournal, 49(1), pp. 1-6.

Kovács, Z., 2009. Social and economic transformation of historical neighbourhoods in Budapest. Tijdschrift voor economische en sociale geografie, 100(4), pp. 399-416.

Kovács, Z. and G. Herfert, 2012. Development pathways of large housing estates in post-socialist cities: An international comparison. Housing Studies, 27(3), pp. 324-342.

Kovács, Z. and Szabó, B., 2016. Urban restructuring and changing patterns of socio-economic segregation in Budapest. In: T. Tammaru, S. Marcińczak, M. van Ham and S. Musterd, eds. Socio-economic Segregation in European Capital Cities. London: Routledge, pp. 238-260.

Kovács, Z. and Tosics, I., 2014. Urban sprawl on the Danube: The impacts of suburbanization in Budapest. In: K. Stanilov and L. Sýkora, eds. Confronting Suburbanization: Urban Decentralization in Postsocialist Central and Eastern Europe. Oxford: Wiley-Blackwell, pp. 33-64.

Kovács, Z., Wießner, R. and Zischner, R. 2013. Urban renewal in the inner city of Budapest: Gentrification from a post-socialist perspective. Urban Studies, 50(1), pp. 22-38.

Krišjāne, Z., Bērziṇš, M. and Kratovitš K., 2016. Occupation and ethnicity: Patterns of residential segregation in Riga two decades after socialism. In: T. Tammaru, S. Marcińczak, M. van Ham and S. Musterd, eds. Socio-economic Segregation in European Capital Cities. London: Routledge, pp. 287-312.

Leetmaa, K. and Tammaru, T., 2007. Suburbanization in countries in transition: Destination of suburbanizers in the Tallinn metropolitan area. Geografiska Annaler, Series B: Human Geography, 89(2), pp. 127-146.

Leetmaa, K., Tammaru, T. and Anniste, K., 2009. From priority-led to market-led suburbanization in a postcommunist metropolis. Tijdschrift voor Economische an Sociale Geografie, 100(4), pp. 436-453.

Leetmaa, K., Kährik, A., Nuga, M. and Tammaru, T., 2014. Suburbanization in the Tallinn metropolitan area. 
This is a draft chapter. The final version is available in Handbook of Urban Segregation edited by S. Musterd, published in 2020, Edward Elgar Publishing Ltd. http://dx.doi.org/10.4337/9781788115605

The material cannot be used for any other purpose without further permission of the publisher, and is for private use only.

\section{Handbook of urban segregation}

In: K. Stanilov and L. Sýkora, eds. Confronting Suburbanization: Urban Decentralization in Postsocialist Central and Eastern Europe. Oxford: Wiley-Blackwell, pp. 192-224.

Marcińczak, S. and Sagan, I., 2011. The socio-spatial restructuring of Łódź, Poland. Urban Studies, 48(9), pp. 1789-1809.

Marcińczak, S., Gentile, M. and Stępniak, M., 2013. Paradoxes of (post) socialist segregation: Metropolitan sociospatial divisions under socialism and after in Poland. Urban Geography, 34(3), pp. 327-352.

Marcińczak, S., Musterd, S., van Ham, M. and Tammaru, T., 2016. Inequality and rising levels of socioeconomic segregation: Lessons from a pan-European comparative study. In: T. Tammaru, S. Marcińczak, M. van Ham and S. Musterd, eds. Socio-economic Segregation in European Capital Cities. London: Routledge, pp. 358-382.

Marcińczak, S., Tammaru, T., Novák, J., Gentile, M., Kovács, Z., Temelová, J., Valatka,V., Kährik, A. and Szabó, B., 2015. Patterns of socioeconomic segregation in the capital cities of fast-track reforming postsocialist countries. Annals of the Association of American Geographers, 105(1), pp. 183-202.

Musil, J., 1993. Changing urban systems in post-communist societies in Central Europe: Analysis and prediction. Urban Studies, 30(6), pp. 899-905.

Musterd, S. and Ostendorf, W., 2012. Inequalities in European cities. In: S.J. Smith, M. Elsinga, L.F. O’Mahony, O.S. Eng, S. Wachter and D. Clapham, eds. International Encyclopedia of Housing and Home. Oxford: Elsevier, pp. 49-55.

Musterd, S., Marcińczak, S., van Ham, M. and Tammaru, T., 2017. Socioeconomic segregation in European capital cities. Increasing separation between poor and rich. Urban Geography, 38(7), pp. 1062-1083.

Ouředníček, M. 2007. Differential suburban development in the Prague urban region. Geografiska Annaler, Series B: Human Geography, 89(2), pp. 111-126.

Ouředníček, M., Pospíšilová, L., Špačková, P., Kopecká, Z. and Novák, J., 2016. The velvet and mild: Sociospatial differentiation in Prague after transition. In: T. Tammaru, S. Marcińczak, M. van Ham and S. Musterd, eds. Socio-economic Segregation in European Capital Cities. London: Routledge, pp. 261-286.

Pichler-Milanović, N., 2014. Confronting suburbanization in Ljubljana: From 'urbanization of the countryside' to urban sprawl. In: K. Stanilov and L. Sýkora, eds. Confronting Suburbanization: Urban Decentralization in Postsocialist Central and Eastern Europe. Oxford: Wiley-Blackwell, pp. 65-96.

Rugg, D., 1985. Eastern Europe. Harlow: Longman.

Ruoppila, S., 2004. Processes of residential differentiation in socialist cities. Literature review on the cases of Budapest, Prague, Tallinn and Warsaw. European Journal of Spatial Development, no. 9.

Shlay, A.B., 2015. Life and liberty in the pursuit of housing: Rethinking renting and owning in post-crisis America. Housing Studies, 30(4), pp. 560-579.

Smith, A. and Timár J., 2010. Uneven transformations: Space, economy and society 20 years after the collapse of state socialism. European Urban and Regional Studies, 17(2), pp. 115-125.

Stanilov, K. and Hirt, S., 2014. Sprawling Sofia: Postsocialist suburban growth in the Bulgarian capital. In: K. Stanilov and L. Sýkora, eds. Confronting Suburbanization: Urban Decentralization in Postsocialist Central and Eastern Europe. Oxford: Wiley-Blackwell, pp. 163-191.

Stanilov, K. and Sýkora, L., 2012. Planning markets, and patterns of residential growth in metropolitan Prague. Journal of Architectural and Planning Research, 29(4), pp. 278-291.

Stevens, M., Lux, M. and Sunega, P., 2016. Post-socialist housing systems in Europe: Housing welfare regimes by default? Housing Studies, 30(8), pp. 1210-1234.

Sýkora, L., 2005. Gentrification in post-communist cities. In: R. Atkinson and G. Bridge, eds. Gentrification in Global Context: The New Urban Colonialism. London: Routledge, pp. 90-105.

Sýkora, L., 2009a. Post-socialist cities. In: R. Kitchin and N. Thrift, eds. International Encyclpedia of Human Geography, Volume 8. Oxford: Elsevier, pp. 387-395.

Sýkora, L., 2009b. New socio-spatial formations: Places of residential segregation and separation in Czechia. Tijdschrift voor Economische en Sociale Geografie, 100(4), pp.417-435.

Szelényi, I., 1987. Housing inequalities and occupational segregation in state socialist cities. International Journal of Urban and Regional Research, 11(1), pp. 1-8.

Szelényi, I., 1989. Eastern Europe in the epoch of transition: Toward a socialist mixed economy? In: V. Nee and D. Stark, eds. Remaking the Economic Institutions of Socialism: China and Eastern Europe. Stanford, CA: Stanford University Press.

Szelényi, I., 1996. Cities under socialism - and after. In: G. Andrusz, M. Harloe and I. Szelényi, eds. Cities after Socialism: Urban and Regional Change and Conflict in Post-Socialist Societies. Oxford: Blackwell, pp. 286-317.

Tammaru, T., Marcińczak, S. and Kukk, K., 2017. Social transformations, housing and socio-economic segregation in the fast-track reform countries. In: P. Vihalemm, A. Masso and S. Opermann, eds. The Routledge International Handbook of European Social Transformations. London: Routledge, pp. 159-171.

Tammaru, T., Leetmaa, K., Silm, S. and Ahas, R., 2009. Temporal and spatial dynamics of the new residential areas around Tallinn. European Planning Studies, 17(3), pp.423-439. 
This is a draft chapter. The final version is available in Handbook of Urban Segregation edited by S. Musterd, published in 2020, Edward Elgar Publishing Ltd. http://dx.doi.org/10.4337/9781788115605

The material cannot be used for any other purpose without further permission of the publisher, and is for private use only.

\section{Do market forces reduce segregation?}

Tammaru, T., Marcińczak, S., van Ham, M. and Musterd, S., eds, 2016b. Socio-economic Segregation in European Capital Cities. London: Routledge.

Tammaru, T., Marcińczak, S., van Ham, M. and Musterd, S., 2016c. A multi-factor approach to understanding socio-economic segregation in European capital cities. In: T. Tammaru, S. Marcińczak, M. van Ham and S. Musterd, eds. Socio-economic Segregation in European Capital Cities. London: Routledge, pp. 1-29.

Tammaru, T., Kährik, A., Mägi, K., Novák, J. and Leetmaa, K., 2016a. The 'market experiment': Increasing socio-economic segregation in the inherited bi-ethnic context of Tallinn. In: T. Tammaru, S. Marcińczak, M. van Ham and S. Musterd, eds. Socio-economic Segregation in European Capital Cities. London: Routledge, pp. 333-357.

Valatka, V., Burneika, D. and Ubarevičienè, T., 2016. Large social inequalities and low levels of socio-economic segregation in Vilnius. In: T. Tammaru, S. Marcińczak, M. van Ham and S. Musterd, eds. Socio-economic Segregation in European Capital Cities. London: Routledge, pp. 313-332.

Węcławowicz, G., 1998. Social polarisation in postsocialist cities: Budapest, Prague and Warsaw. In: G. Enyedi, ed. Social Change and Urban Restructuring in Central Europe. Budapest: Akadémiai Kiadó, pp. 55-64. 